\title{
Emerging Markets and the Pacific Alliance
}

\author{
Luis F. Copertari \\ Computer Engineering Program, Autonomous University of Zacatecas (UAZ), Zacatecas, México \\ Email: copertari@yahoo.com
}

Received 22 July 2016; accepted 16 August 2016; published 19 August 2016

Copyright @ 2016 by author and OALib.

This work is licensed under the Creative Commons Attribution International License (CC BY).

http://creativecommons.org/licenses/by/4.0/

(c) (i) Open Access

\begin{abstract}
Humanity faces today several challenges, from environmental deterioration to consumerism and a demand from the economy to sustain exponential growth over the long term. A new middle class in emerging markets in Latin America and Asia is gaining purchasing power. The issue of exponential growth is explored as to whether or not it is really sustainable based on a computational experiment. Also, the very idea of money is scrutinized. A new complementary currency called the PAL (for Pacific Alliance dollar) is proposed and the business model is pictured and explained. The way in which such new currency would be valued is illustrated. Finally, the most relevant issues are discussed and some examples of the types of business to promote are considered.
\end{abstract}

\section{Keywords}

Capitalism, Middle Class, Exponential Growth, Complementary Currencies

Subject Areas: Monetary Economics

\section{Introduction}

The exponential growth demanded to global companies is beginning to be too excessive. This paper explores the validity of exponential growth in the long term in light of some of the challenges being faced by humanity today.

The very concept of money is considered, and a new currency called the PAL is introduced, including its business model and its valuation mechanism. This currency is meant for the creation of a new emerging economy in Latin America and Asia based on the comparatively low wealth of a new type of middle class in this region, when compared to the traditional wealth of the US middle class. Despite of their relative low wealth, this new middle class is becoming very large in volume, and thus it is starting to make sense to invest aimed at this new emerging middle class.

\section{Current Challenges}

Humanity faces today several challenges. To me, the situation is as the one shown in Figure 1. There is a not so

How to cite this paper: Copertari, L.F. (2016) Emerging Markets and the Pacific Alliance. Open Access Library Journal, 3: e2919. http://dx.doi.org/10.4236/oalib.1102919 


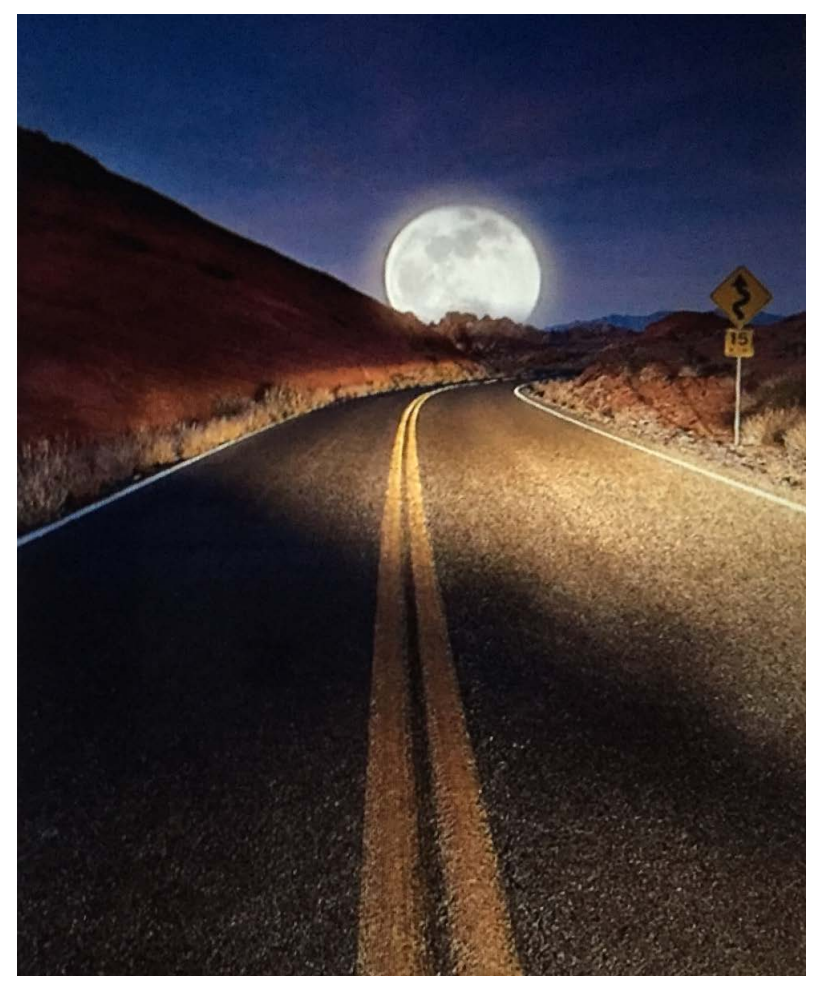

Figure 1. Humanity today.

clear sign of curves ahead, with the dream of leaping towards the moon, but a real challenge in the road to come. There are several difficulties that need addressing. First of all is the ecological and climate change tragedy. The impulse towards more and more consumerism (pictured graphically in Figure 2) driven by multinationals in which more and more is produced and consumed in a never ending chase for the money we would realize we do not really need only if we were not so blind, is more or less slowly sending us to our own destruction. It is easy to send the bill of unaccounted costs to the environment, but it is really hard to take a step back and see things as they are.

The problem is that companies are struggling trying to become profitable demanding a compound interest rate of wealth creation, while at the same time focusing on volume instead of value.

Carbon dioxide concentrations have risen to 402.23 ppm (parts per million) according to Nasa Climate Change [1]. The levels of the sea are rising at a rate of $3.4 \mathrm{~mm}$ per year (Nasa Climate Change [2]). It may be that we have been pushing neoliberalism too far (Harvey [3]). Clearly, we are heading towards the abyss unless we make prompt changes in the usual way things are.

Small and medium size companies, the ones that typically create most of the jobs, are being choked out of the market or simply bought up by large corporations. This paper is an attempt to provide a means towards the solution of these problems.

It is clear that a new middle class in the emergent economies of Latin America, China, India and some other countries in Asia is acquiring purchase power. It is not the same purchase power of the past in developed economies, where they aspired to a house, a second car and vacations. This new middle class wants to be able to pay for his cell phone (the Internet is now a must have), its electricity bill and enhancements to the house such as a new floor. However, given the dimension of this new form of middle class, the total volume of sales for them should be higher than the one for traditional middle classes in developed economies.

The proposal is to create a new currency (although not exactly a complementary currency) for the countries within the Pacific Alliance including in principle Canada, the United States, México, Ecuador, Chile and perhaps Perú as well as (if feasible) other countries in Latin America and Asia interested in being part of the solution rather than part of the problem. The new currency being proposed would be called the Pacific Alliance dollar (PAL; the plural would be PALs). 


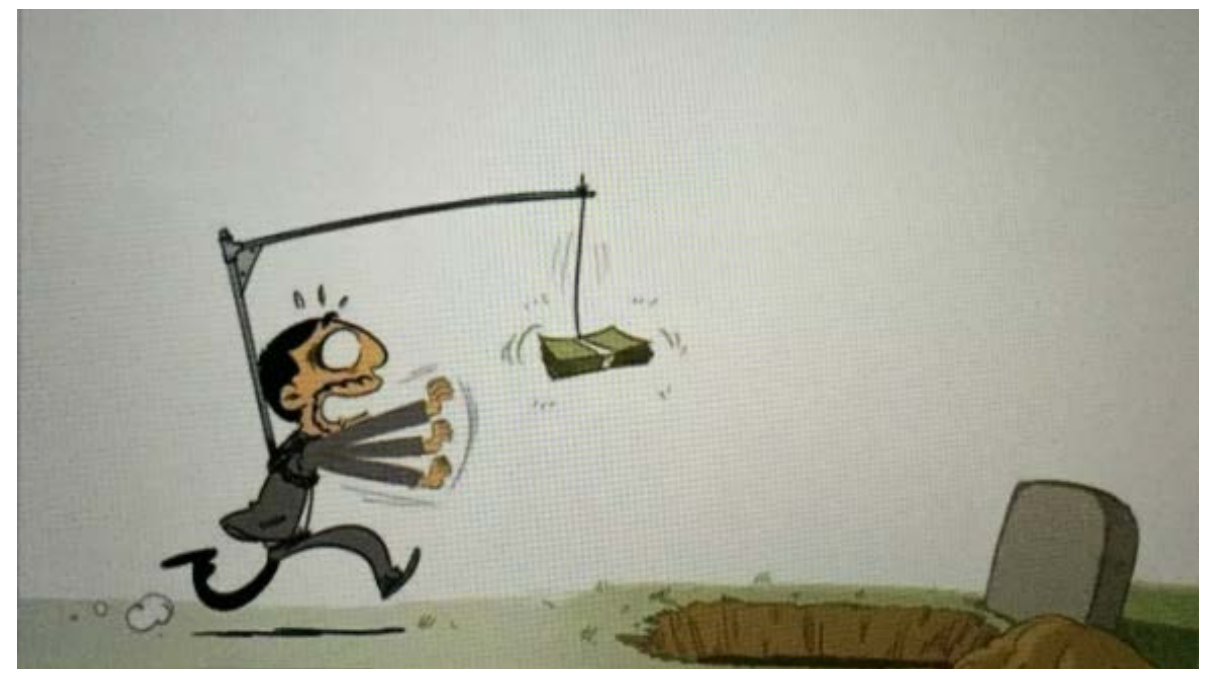

Figure 2. The life of common man.

\section{Is Exponential Growth in the Economy Sustainable?}

The first and most critical issue to explore is whether exponential growth in the economy is sustainable or not. Harvey [4] states that exponential growth cannot go on over the long term. He says that after a while of actual exponential growth, limits to capital due to resource depletion, environmental deterioration or other contradictions of capital make continuing exponential growth impossible. This issue is a matter of considerable debate and it is one of the focal points to be made. Figure 3 shows exponential yearly growth at a compound interest rate of $10 \%$ per year. Compound interest rate means that interest is generated not only on the capital but also on the interest previously generated. That is how compound exponential growth looks like over the time.

For banks to demand compound interest growth to companies is unrealistic. It is impossible to sustain such kind of growth over the long term. Although initially exponential growth may look feasible, over the long term it cannot happen. Or does it?

Kurzweil [5] makes the case for what he calls the law of accelerating returns (LOAR) in technological development. LOAR is equivalent in economy to exponential growth. His most compelling argument is that although there are some constraints on exponential growth, paradigm shifts take place that make exponential growth feasible again in a series of $\mathrm{S}$ shaped curves that accelerate in growth as time goes by so that the overall tendency is still exponential growth.

Figure 4 shows the same exponential growth as in Figure 3, except that now a logarithmic scale is used so that exponential growth almost looks like a straight line.

So is compound exponential growth possible or not? In order to answer that question, an experiment is due. Consider the case of a hypothetical lake in which algae grow. Algae have the ability to duplicate in every generation. Thus, the potential for a very strong exponential growth exists. Of course, it is not practical to try and make this experiment in real life. Thus, a simulation would be required. Suppose that the lake is represented as a grid of 100 by 100 pixels, and that each black pixel represents one alga cell, and each white pixel an available space in the lake. Let also introduce an environmental constraint (assumption); in this case being that algae cannot reproduce by occupying a pixel that is already occupied. How could a paradigm shift be represented in this case? That can take the form of a jump into an extra dimension of space. Thus, once the two dimensional grid has been fully occupied, a three dimensional grid of 100 by 100 by 100 pixels is considered so that now each alga in the surface would sink and start reproducing in each generation throughout the whole lake and not just its surface. The idea can be algorithmically and mathematically extended into a fourth dimension as well as a one dimension for the beginning of the experiment. Consequently, in the one dimensional case a straight line of 100 pixels is the space being allowed and only 1 pixel is initially occupied. This first pixel is placed at position 25 of the line. Once the whole 100 pixels line has been occupied, each pixel accommodates at random in its corresponding column in the two dimensional grid and growth continues. Then, once the $100 \times 100(10,000)$ pixels have occupied the two dimensional grid, each pixel sinks into a three dimensional grid and growth is now al- 


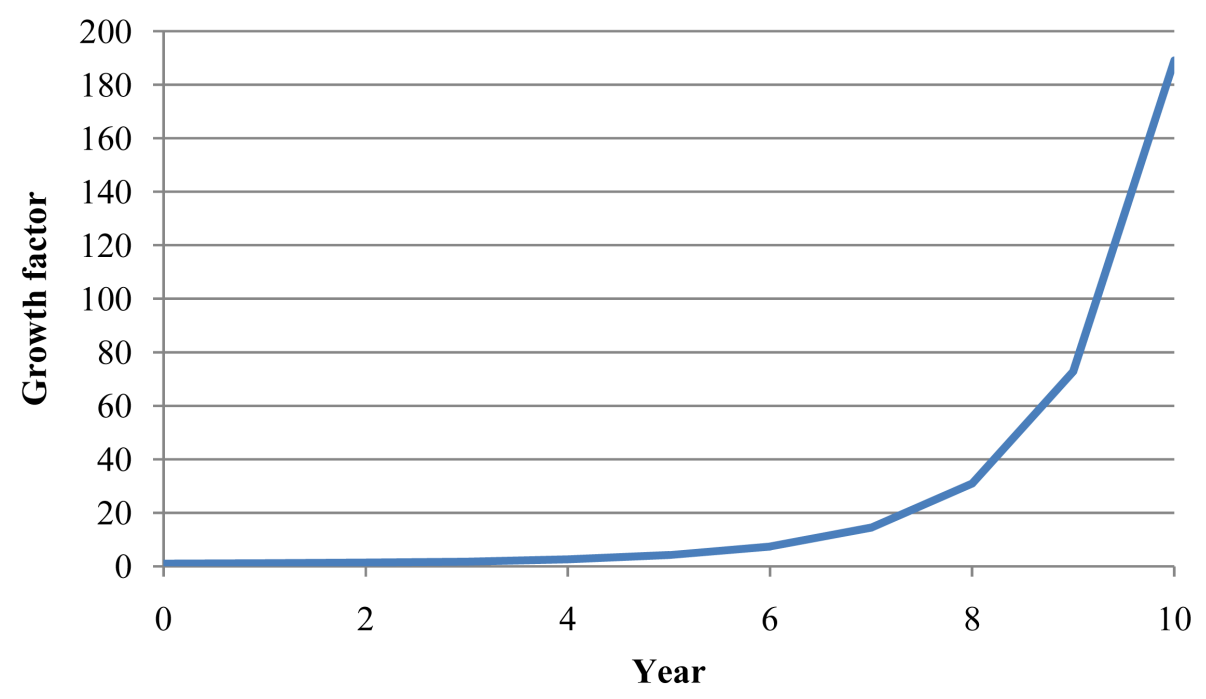

Figure 3. Exponential compound growth at $10 \%$ yearly interest over 10 years.

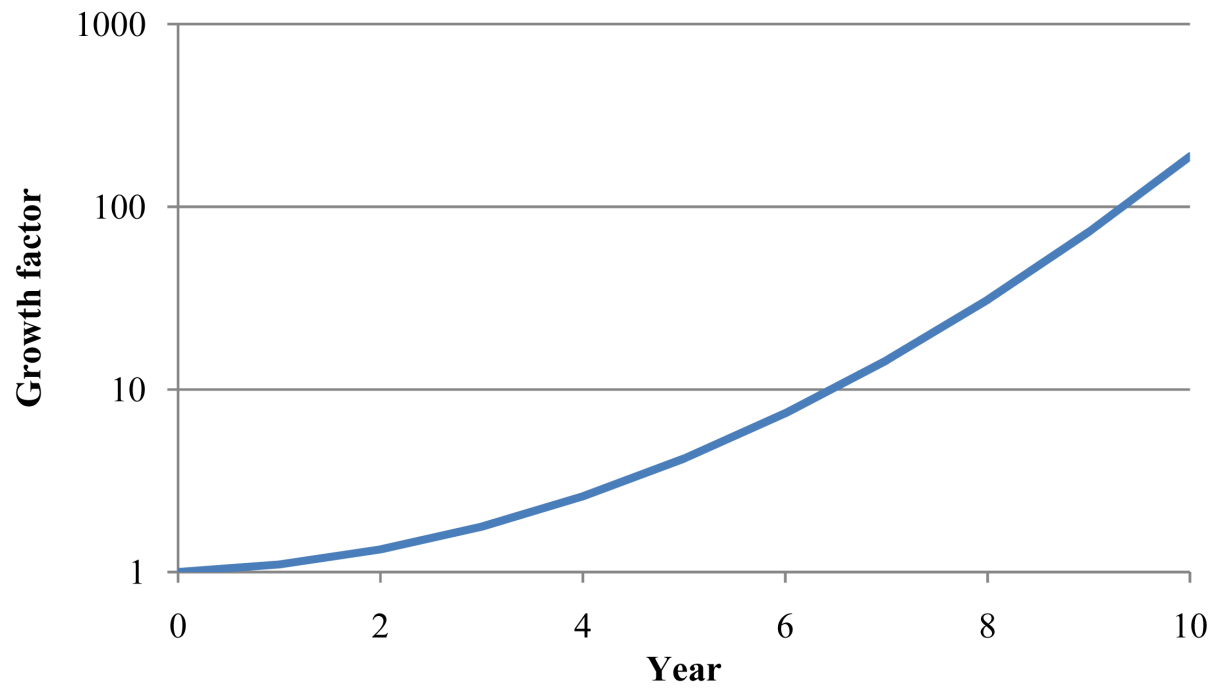

Figure 4. Exponential compound growth at $10 \%$ yearly interest over 10 years in a logarithmic scale.

lowed to continue once again. Finally, and only by way of a mathematical and algorithmically generated "reality" of a four dimensional grid of $100 \times 100 \times 100 \times 100(100,000,000)$ pixels is further considered.

What are the results of this experiment? For the one dimensional case, exponential growth is only possible for the second generation and the third generation (1, 2, and 4 pixels). Figure 5 shows such growth plotted. Figure 5 does not even show an $\mathrm{S}$ shaped figure due to the limited capacity of growth in a one dimensional line.

Figure 6 is more interesting than Figure 5. Now the first paradigm shift has taken place, and growth in a two dimensional grid is allowed. In this case a clear S shaped curve appears, which indicates that initially there is exponential growth, but after a while such growth becomes linear and after that not even linear but asymptotical. In fact, generations 1 through 4 show true exponential growth: 100, 200, 400 and 800 pixels. Generation 5 shows close to exponential growth (1547 pixels compared to the ideal 1600 pixels). After that, exponential growth is no longer sustainable.

For the three dimensional case, the growth is also S shaped, as illustrated in Figure 7. The S shaped form is even clearer. Now, generations 1 through 4 show true exponential growth (1000, 2000, 4000 and 8000 pixels), generations 5 and 6 show close to exponential growth (159,997 and 319,720 compared to the ideal 160,000 and 320,000 pixels). After that follows linear growth and then asymptotical growth. 


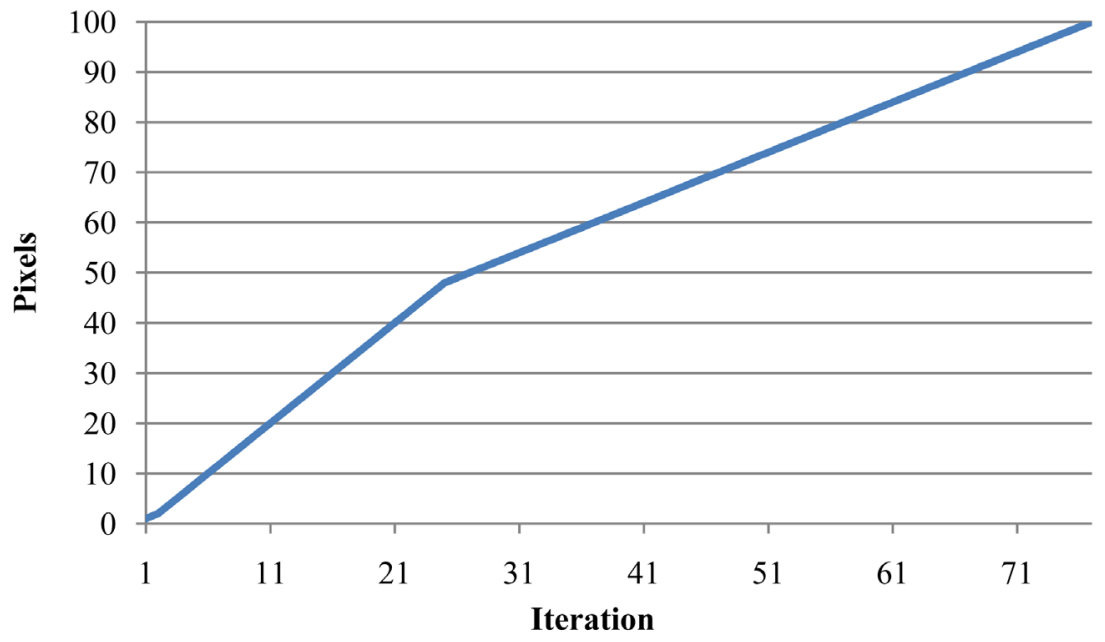

Figure 5. Growth in the one dimensional case experiment.

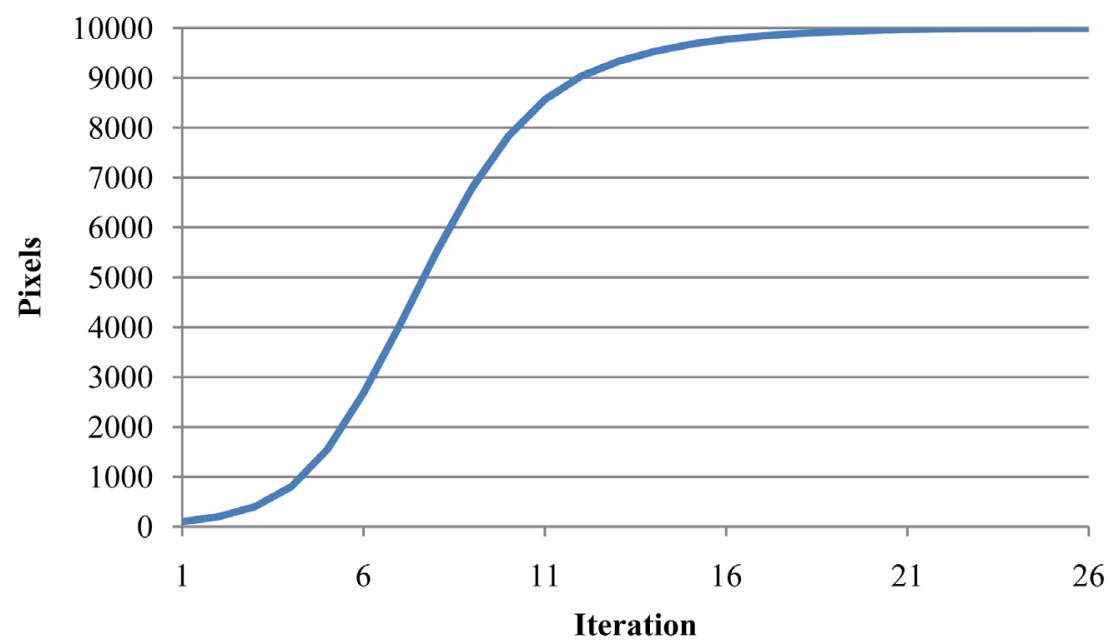

Figure 6. Growth in the two dimensional case experiment.

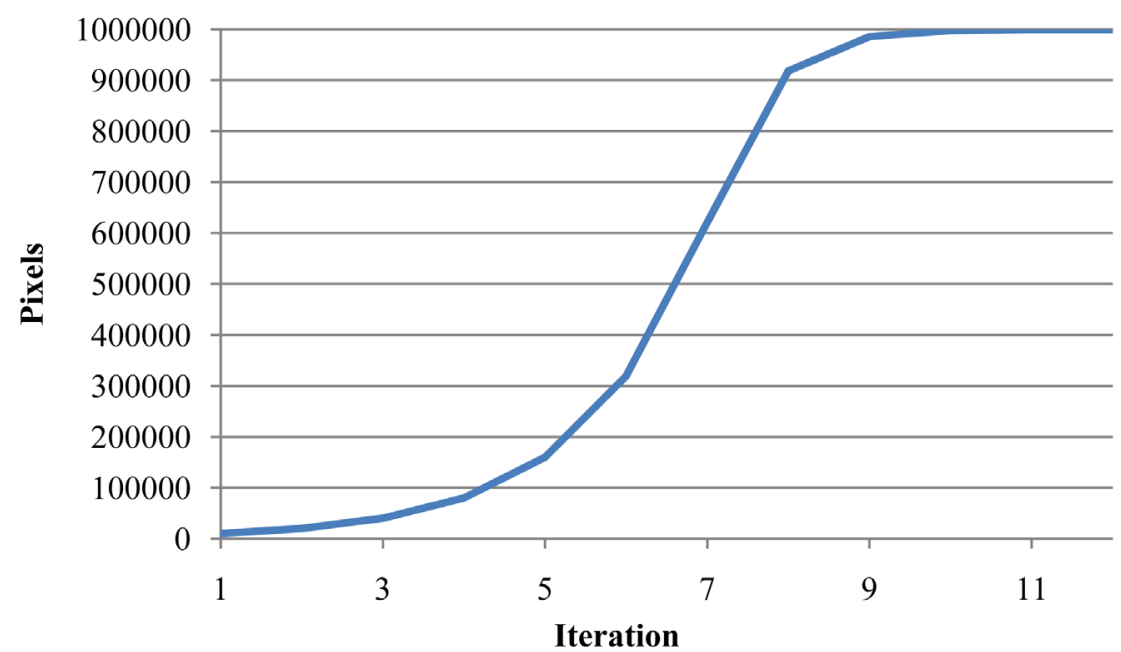

Figure 7. Growth in the three dimensional case experiment. 
Finally, there is the four dimensional idealization, which is illustrated in Figure 8. In this case, true exponential growth happens from generation 1 through generation $5(1,000,000,2,000,000,4,000,000,8,000,000$ and $16,000,000$ pixels). Generation 6 shows close to exponential growth (31,999,309 versus the ideal 32'000,000 pixels). After that follows linear growth and finally asymptotical growth.

But then again, is the overall growth through the three successive paradigm shifts (from 1D to 2D, from 2D to $3 \mathrm{D}$, and from 3D to 4D) accelerating? The answer is no. The first case (1D) took 77 generation. The second case (2D) took 26 generations. The third (3D) and fourth (4D) cases took each 12 generations to be completed. Thus, the $\mathrm{S}$ shapes are not accelerating in speed as paradigm shifts occur. Figure 9 illustrates the growth through paradigm shifts in a logarithmic scale (the linear scale is useless now). A growth pattern similar to the one in Figure 4 is not happening. Thus, it seems that exponential growth is not sustainable in the long term when considering environmental constraints, even when paradigm shifts exist.

On the other hand, based on the theory of constraints (Goldratt [6]; Goldrattand Cox [7]) the strength of a system is based on its weakest links. Thus, it is possible to join the bottom points in Figure 9 using a red dotted line. It can be seen that even in the worst case there is a straight line on a logarithmic scale. A straight line on a logarithmic scale does indicate exponential growth. Thus, although the $\mathrm{S}$ shaped curves are not always accele-

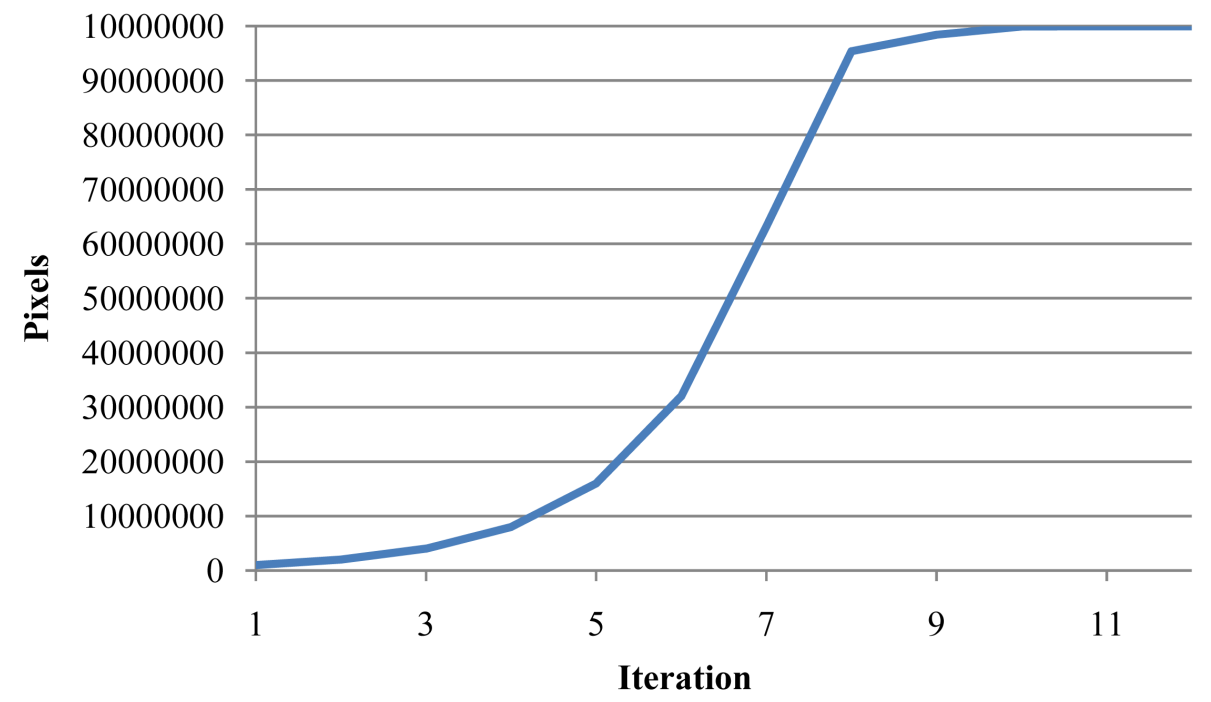

Figure 8. Growth in the four dimensional case experiment.

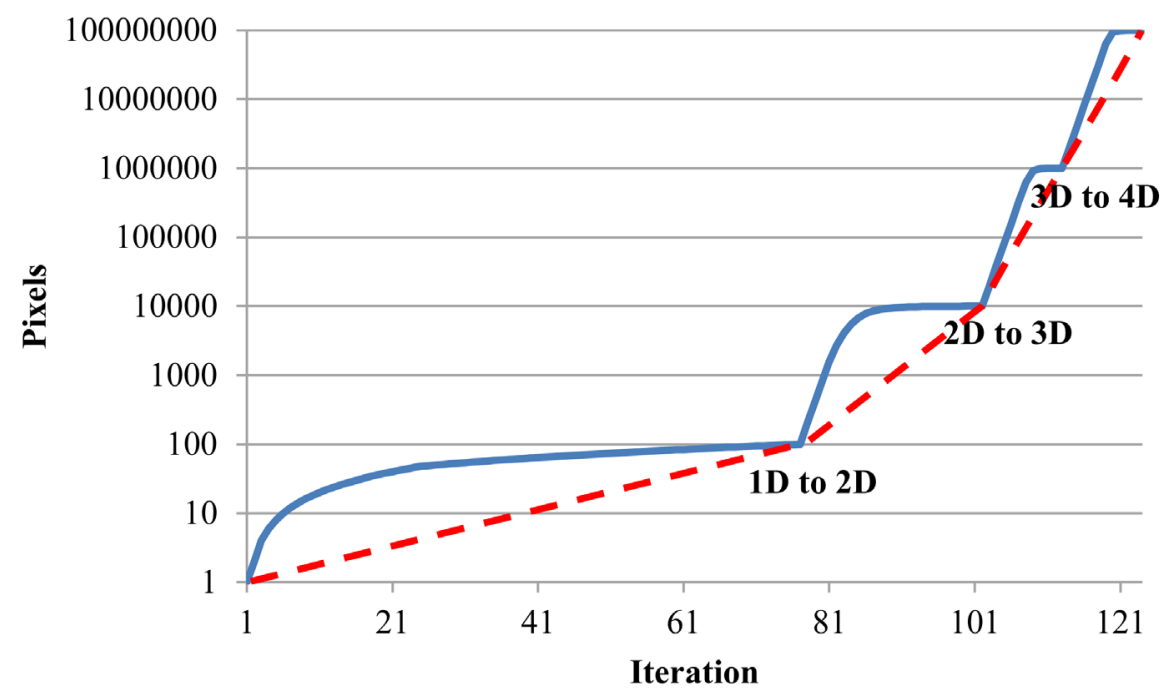

Figure 9. Growth through paradigm shifts in the experiment. 
rating in speed, such is compensated by an exponential increase in algae. However, the rate of the exponential growth seems to be reducing from paradigm to paradigm shifts. Eventually, if the assumptions of the system do not change, the exponential growth could be threatened.

\section{What Is Money?}

The second really important issue to tackle is the definition of money. But, what is money? According to Harvey [4] money is "a means whereby I can make a claim on the social labour of others: that is, a claim in that labour which is expended on the production of goods and services for others in the marketplace." (p. 25).

To really understand money requires us to immerse ourselves deeply into the issue. In order to start understanding what money is, it is useful to consider the historical evolution of money. Greco [8] identifies five types of money: a) barter trade; b) commodity money; c) symbolic money; d) credit money; and e) credit clearing.

Barter trade is the first and most basic way of exchanging goods and services. If A has something that $B$ needs and B has something that A needs, they could agree on exchanging given quantities of such products or services. It could get more complicated if A has something that B needs, B has something that $\mathrm{C}$ needs and $\mathrm{C}$ has something that A needs, thus completing the exchange circle. Barter trade was the first step in human civilization towards goods and services exchange. Commodity money is based on a good or service that has intrinsic value (use value) in itself and can be used to perform the function of exchange value. Examples are cigarettes, coffee seeds, gold, and so on. Symbolic money are receipts received for a deposit of seeds, gold or some other valuable good that can be used as exchange money. Credit money is one of the actual forms money today takes place. For example, a mortage on a house is given in exchange for credit on a bank account (although such credit is actual money to be used). The concept of fractional deposits or fractional reserve banking is very important here (McLeay, Radia and Thomas [9]). Banks only do have a fraction on a real deposit for the credit they issue. This fact is responsible for a large number of economic crises (Hallsmith and Lietaer [10]; Lietaerand Dunne [11]). Finally, there is potential for the use of a credit clearing system, in which A owes to B, B owes to C, C owes to $\mathrm{D}$ and $\mathrm{D}$ owes to $\mathrm{A}$ (or any other more complex arrangement) and all transactions are cleared tending to a zero balance (when things operate properly). The latter is the potential for a new form of money based on electronic clearing transactions. Most forms of complementary currencies operate based on this principle.

\section{Classifying the PAL}

The currency being proposed is called the PAL (for Pacific Alliance). It is a Business to Business (B2B) currency as being initially designed (New Economics Foundation [12]). But how should we classify this new currency? Table 1 shows several examples of complementary currencies and the way they can be classified (Blanc [13]).

The PAL is a Business to Business currency, it is regional because it is meant for countries being part of the Pacific Alliance (perhaps based on countries being part of the Trans Pacific Pact or TPP), and it is designed to serve a social purpose (promote small and medium sized businesses and ecological/environmental commitment).

\section{The PAL Business Model}

The PAL business model is summarized in Figure 10. The issuer of the currency can be the national bank of each of the countries participating. The issuer makes a loan in PAL to business A. Business A in return gives the

\begin{tabular}{cc} 
Table 1. Complementary currencies classification. \\
\hline Business to Business & Barter Industry “Trade Dollars” \\
Local/Regional & Bristol Pounds, Ithaca HOURs, Banco Palma \\
Time & Time Dollars, Credits AKA “Time Banking” \\
Social Purpose & Nu-Spaarpas, HERO Rewards “Merits” \\
Loyalty & Frequent Flier Miles, Coffee Cards \\
Reputation & Ebay, Amazon Seller Ratings \\
Cryptographic & Bitcoin, Ripple, Ethereum \\
\hline
\end{tabular}




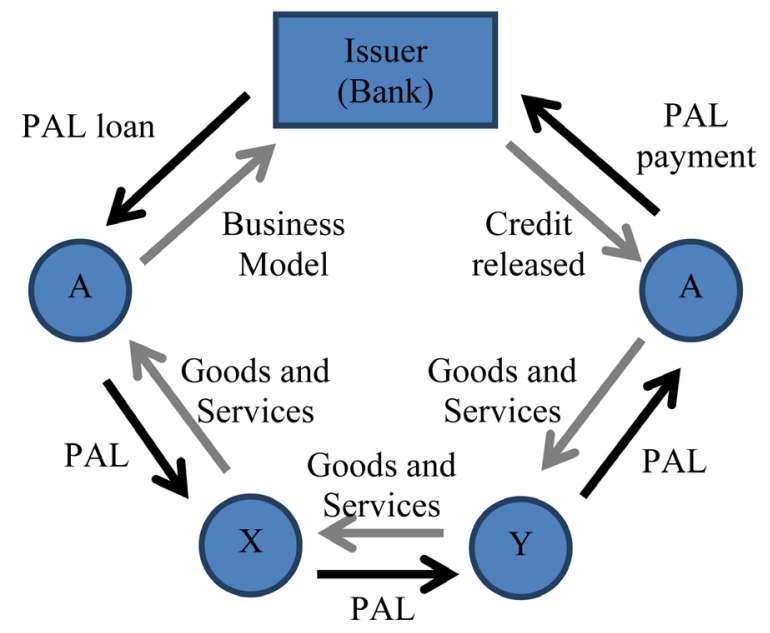

Figure 10. The PAL business model.

issuer its business model. Let us say the amount being borrowed is PAL $\$ 100$. In order to generate its product and/or service, A buys goods and/or services from X by paying using a part of its PAL \$100. These goods and/or services can be raw materials or equipment. Assume A spends PAL \$50 in raw materials purchased from $\mathrm{X}$. If $\mathrm{X}$ also works using PALs, it is easier for A to make the transaction. If not, A would have to exchange its PALs into the local currency. In this way the use of PALs is promoted. Now assume X operates in México so it demands Mexican pesos (MXN). Then A would have to exchange its PALs for USDs (assume the exchange rate if $1 \mathrm{PAL} / \mathrm{USD}$ ) and those USDs for MXNs (assume $20 \mathrm{MXN/USD),} \mathrm{which} \mathrm{means} \mathrm{A} \mathrm{would} \mathrm{have} \mathrm{MXN} \mathrm{\$ 1000.}$ The Mexican National Bank (Banco de México) would have to exchange PALs for USDs and then USDs for MXNs (or directly exchange PALs for MXNs). The tricky part is that there is a spread (differential) between the buying and selling of USDs and MXNs. This differential is kept by the bank in exchange for its services. Thus, assuming all transactions are done in México and that only PALs are used, A should be able to sell its product/service to Y in exchange for PALs. If Y does not operate using PALs, then it would have to exchange MXNs for USDs and USDs for PALs, thus losing some money in the exchange back to PALs. Even further, the product/service created by A would be worth more than PAL \$100 because of the value added it would have. Say A sells to Y its product/service for PAL \$120. Where would the PAL \$20 not introduced in the system come from? The issuer would have to create it out of thin air. This does not create inflation because there is a product/service backing that money (Greco [8]). Furthermore, there is an incentive for all the agents in the economy to operate solely on PALs so that nobody loses money on the currency exchange spreads.

\section{The Big Mac Index and PAL Valuation}

But how could a new currency (PAL), valid throughout all of the Pacific Alliance, be valued when compared to the domestic currencies of each country? For this, the Big Mac index can be used (The Economist [14]). Keep in mind that for a real implementation of the Pacific Alliance, a basket of commodities including even the value of services should be used instead of a single product.

Consider, for example, México and the US in January, 2015. What should the value of a PAL be in terms of Mexican pesos (MXN)? For that time, the price of a Big Mac was MXN \$49 per Big Mac. In the same period, a Big Mac cost in the United States USD \$4.79 per Big Mac. Thus, the implied value of the US dollar compared to the Mexican peso is $\mathrm{I}_{\mathrm{MXN}}=\$ 49 / 4.79=$ MXN \$10.23 per USD. Also, the official value of the Mexican peso (Banco de México, Peso exchange rates versus the US dollar [15]) was $\mathrm{O}_{\mathrm{MXN}}=\mathrm{MXN} \$ 14.66$ per USD. The Big Mac index valuation used here is $\mathrm{V}=\left(\mathrm{O}_{\mathrm{MXN}}-\mathrm{I}_{\mathrm{MXN}}\right) / \mathrm{I}_{\mathrm{MXN}}=(14.66-10.23) / 10.23=43.3 \%$ of overvaluation of the US dollar versus the Mexican peso. One unit of a PAL (PAL \$1) should equal the implied valuation of the Mexican peso, that is MXN \$10.23 per PAL, so that the US dollar is never overvalued nor undervalued versus the PAL.

Doing a comparison throughout the most relevant countries in America for which data was available (The Economist [14]; Banco de México, Foreign Exchange Rates for the US dollar [16]), yields Figure 11. As can 


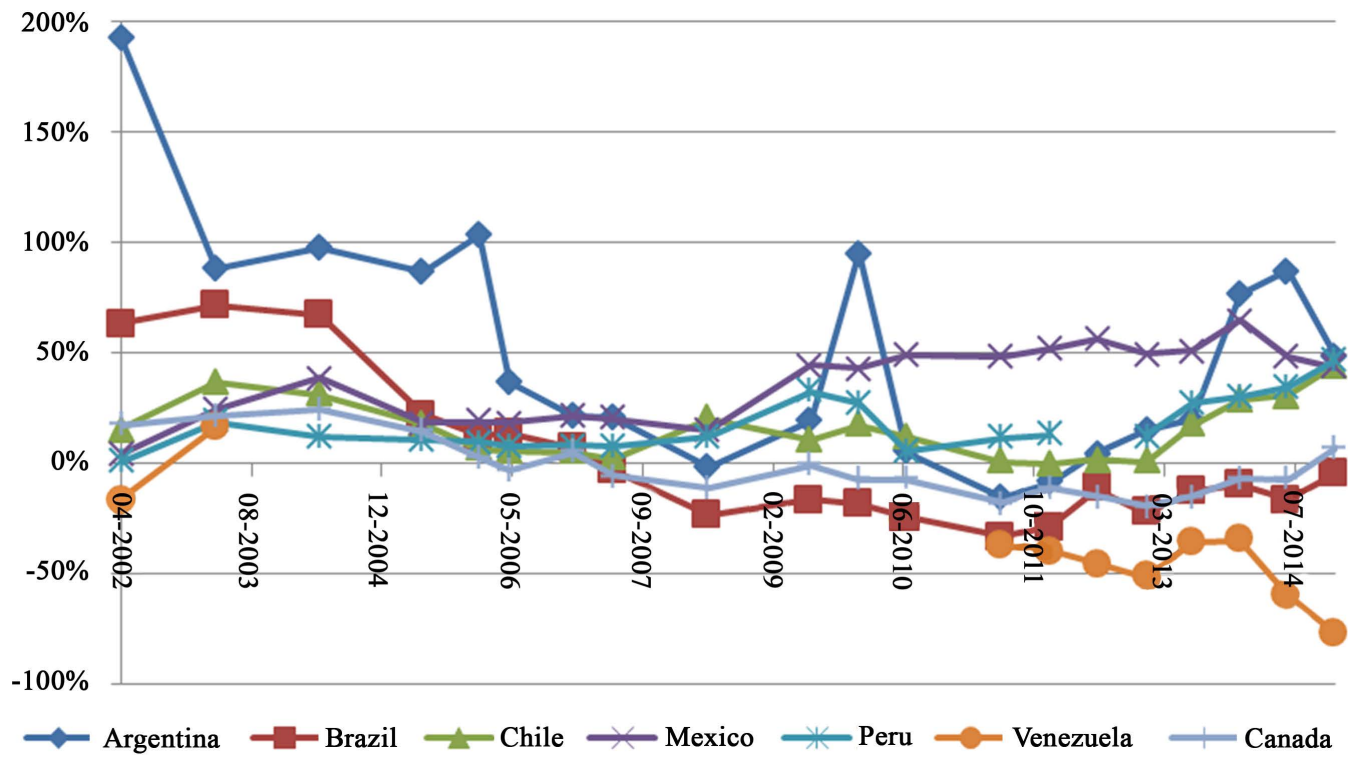

Figure 11. Overvaluation or undervaluation of the U.S. dollar versus the domestic currencies in America according to the Big Mac index analysis for the data available.

be seen, Argentina is the worst case of US dollar overvaluation. Canada, for comparison purposes, seems to behave reasonably well, having first an overvalued US dollar and then an undervalued US dollar. México shows a consistent and slight overvaluation of the US dollar. Brazil shows overvaluation and then slight undervaluation. Venezuela does not even have reliable information available for the whole period of the analysis, the analysis going from April, 2002 to January, 2015. Peru has a slight lapse of not reliable information around July, 2012. Chile shows slight overvaluation of the US dollar.

In the case $\mathrm{n}$ different products or services are considered, let $\mathrm{w}_{\mathrm{k}}$ be the weight given to product/service $\mathrm{k}$ and $\mathrm{p}_{\mathrm{k}}$ be the price of product/service $\mathrm{k}$. Then, Equation (1) can be used to calculate the weighted price p, where Equation (2) must be satisfied.

$$
\begin{gathered}
p=\sum_{k=1}^{n} w_{k} p_{k} \\
\sum_{k=1}^{n} w_{k}=1
\end{gathered}
$$

Saaty’s Analytic Hierarchy Process (Saaty [17]) can be used to calculate the corresponding weights.

\section{Discussion}

Economies with national currencies are not robust. Two indicators of an economy are important: efficiency and resiliency (Hallsmith and Lietaer [10]). Although having one currency as legal tender is efficient, it is not the most robust way to operate. Economies are like ecological systems: a variety of currencies increases resiliency against crises. That is the reason why the PAL (as well as an unlimited number of complementary currencies operating for other purposes) provides an opportunity if used properly. Nevertheless, the PAL is meant as a regional currency (countries member of the Pacific Alliance or more specifically, the Trans Pacific Pact or TPP), not a local currency. The USA, México, Chile, Perú, Australia, New Zealand, Singapur, Brunei and Vietnam have been reported to be part of the TPP (Ackerman [18]). Also, the issuers are supposed to be banks, which are not known for having the interests of the people as their core value.

That is why by design banks should give priority to loans in PALs to small and medium sized businesses, especially if they have an environmental focus as part of their business process. What kind of businesses should be given priority? Here are some simple and first attempt examples: 1) a small clothes manufacturing company that uses high efficiency solar panels for powering their operations; 2) a small marmalade making company using solar powered stoves (which, if possible, buys its raw materials from local farmers growing organic food); 3) a small company that grows organic food using hydroponics (in this case the environmental contribution is not 
wasting water plus not using pesticides); 4) selling wind generated electricity to the electrical grid; 5) planting several trees and making sure these trees get to grow for each tree used to produce paper.

\section{Conclusion}

Clearly, the emphasis for the PAL should be fostering small and medium sized businesses which have local operations if possible even if their product is global. The future seems to be serving this new kind of middle class (the one in developing economies in Latin America and Asia). The PAL is meant to help the creation of businesses by a portion of this new middle class people in emerging economies. It is not that the idea is going against large corporation, just that large corporations typically do not need special assistance to keep going. The new marketing possibilities offered by this emerging middle class are relatively new, so trying to operate by contributing to the creation of small and medium sized businesses in these emerging markets having an ecological contribution seems to be a good idea towards a better and sustainable future.

\section{References}

[1] NASA Climate Change (2016) Global Climate Change. Vital Signs of the Planet. Carbon Dioxide. http://climate.nasa.gov/vital-signs/carbon-dioxide/

[2] NASA Climate Change (2016) Global Climate Change. Vital Signs of the Planet. Sea Level. http://climate.nasa.gov/vital-signs/sea-level/

[3] Harvey, D. (2005) A Brief History of Neoliberalism. Oxford University Press, New York.

[4] Harvey, D. (2014) Seventeen Contradictions and the End of Capitalism. Oxford University Press, New York.

[5] Kurzweil, R. (2005) The Singularity Is Near: When Humans Transcend Biology. Penguin Books, New York.

[6] Goldratt, E.M. (1992) El Síndrome del Pajar. Ediciones Castillo.

[7] Goldratt, E.M. and Cox, J. (1993) La Meta. Ediciones Castillo.

[8] Greco Jr., T.H. (2009) The End of Money and the Future of Civilization. Chelsea Green Publishing, White River Junction.

[9] McLeay, M., Radia, A. and Thomas, R. (2014) Money Creation in the Modern Economy. Bank of England Quarterly Bulletin, Q1, 1-14.

[10] Hallsmith, G. and Lietaer, B. (2011) Creating Wealth: Growing Local Economies with Local Currencies. New Society Publishers, Gabriola Island.

[11] Lietaer, B. and Dunne, J. (2013) Rethinking Money: How New Currencies Turn Scarcity into Prosperity. BernettKoehler Publishers, Inc., San Francisco.

[12] New Economics Foundation (2015) People Powered Money. New Economics Foundation, London.

[13] Blanc, J. (2011) Classifyin “CCs”: Community, Complementary and Local Currencies Types and Generations. International Journal of Community Currency Research, 15, D, 4-10.

[14] The Economist (2015) The Big Mac Index. http://www.economist.com/content/big-mac-index

[15] Banco de México (2015) Tipo de cambio promedio del período. (Peso exchange rates versus the US Dollar.). http://www.banxico.org.mx/SieInternet/consultarDirectorioInternetAction.do?accion=consultarCuadro\&idCuadro=CF $\underline{86 \& \text { sector }=6 \& \text { locale }=\text { es }}$

[16] Banco de México (2015) Tipos de Cambio para Revalorización de Balance del Banco de México. (Foreign Exchange Rates for the US Dollar.) http://www.banxico.org.mx/SieInternet/consultarDirectorioInternetAction.do?accion=consultarCuadro\&idCuadro=CF 336\&sector $=6 \&$ locale $=\mathrm{es}$

[17] Saaty, T.L. (1980) The Analytic Hierarchy Process. McGraw-Hill.

[18] Ackerman, J.M. (2015) La privatización de México. http://www.proceso.com.mx/419003/la-privatizacion-de-mexico-dejar-en-borrador 